\title{
A Wantless, Workless World: How the Origins of the University Can Inform Its Future
}

\author{
Nathan Schneider \\ University of Colorado Boulder
}

\section{Preprint}

Reviewed and accepted for Peters, M. A., Jandrić, P., and Means, A. J. (eds.), Education and Technological Unemployment (Springer, 2019).

From China to North Africa to Europe, the earliest institutions of higher education arose as a set of strategies to protect and encourage practices of productive leisure. These were knowledgeproduction practices the surrounding social and economic order might not otherwise have seen fit to value: self-directed time organized to meet collectively agreed-upon standards. Practices of productive leisure have also become targets for colonial regimes seeking to undermine local civilizations for their own ends. Today, in an era of growing labor precarity and the specter of technological unemployment, higher education is poised to ensure that the benefits of the transformation underway circulate to a broader set of people than is currently the case. Updating the medieval guild structure of universities with cooperative enterprise, and platform cooperativism in particular, can facilitate the capture and sharing of economic surplus. By protecting productive leisure through higher education, automation can yield widespread dividends of liberated time.

Nathan Schneider is an assistant professor in the Department of Media Studies at the University of Colorado Boulder. His most recent book is Everything for Everyone: The Radical Tradition That Is Shaping the Next Economy (2018), and he co-edited, with Trebor Scholz, Ours to Hack and to Own: The Rise of Platform Cooperativism, a New Vision for the Future of Work and a Fairer Internet (2016). He has published articles in publications 
including The New York Times, The Sociological Review, and The Chronicle of Higher Education. His website is nathanschneider.info.

Keywords: cooperatives, elemental media, higher education, medieval history, time, working hours

\section{Faculty Meetings}

It is common practice in academic settings for professors to complain about their faculty meetings. A stew of lingering interpersonal conflicts, externally imposed constraints, and inadequate procedure can lend such gatherings a sense of futility; they can seem singularly discouraging. Yet faculty meetings are also a singularly democratic form of management in an economy that more often seeks to govern workplaces by fiat or algorithm. These meetings are living remnants of a pre-industrial corporate form, the self-governing medieval guild, which modern universities have adapted into a still irreplaceable mechanism for education and research. Perhaps the scorned faculty meeting deserves more credit.

Discussion about the future of higher education tends to focus on how universities might better conform to present and predicted market dynamics (e.g., Etzkowitz, Webster, Gebhardt, \& Terra, 2000). Less common are considerations of historical patterns that have proved remarkably resilient, which might serve as the basis of the next reinvention-patterns embedded in such commonplace activities as faculty meetings. If it is true that the economies of labor and education are due for a drastic, technology-induced realignment, such patterns can be useful reminders of what the university is for, apart from the utilitarian exigencies it has come to serve in our own fleeting contexts.

This essay considers higher education not through the lenses of pedagogy or philosophy, but as a domain of institutional design. I approach these institutions less in legal or managerial terms than as elemental media (Peters, 2015) that shape the social and economic environment - as media, what affordances do these institutions offer and what do they inhibit? What signals does their presence transmit?

I will first review how early institutions of higher education arose, in three different societies, as a set of strategies to protect and encourage knowledgeproduction practices that I describe as productive leisure: self-directed time organized to meet collectively agreed-upon standards. These practices, which 
the surrounding social and economic order might not otherwise have seen fit to value, have transformed their surroundings, and they have become vital fixtures of sophisticated civilizations. Practices of productive leisure have also become targets for colonial regimes seeking to undermine such civilizations for their own ends.

Today, an existential threat to the social order as we know it comes in the form of technological disruption, automation, and the business models that organize them. I suggest that platform cooperatives (Scholz \& Schneider, 2016), combining networked technology and democratic governance, are a promising strategy for protecting productive leisure. But this is not a merely defensive posture. Such cooperative higher education can also serve as a means of ensuring that the benefits of the transformation underway circulate to a broader set of people and purposes than is currently the case. In particular, by protecting productive leisure through higher education, economic upheavals can yield widespread dividends of liberated time.

Such higher education can help people meet their immediate needs while also transforming the order in which they live. It can reverse trends of instrumentalism and colonization. As it has before, higher education can lead social transitions, rather than merely adapting to them. This is a strategy for the present founded on patterns of the past.

\section{Early Universities as Institutional Adaptations}

The apparent etymology of the word university has tempted commentators to wax poetic about the institution's transcendent purpose. John Henry Newman (1905) opened his Idea of a University by defining it as "a place of teaching universal knowledge" (p. ix); the weightiest word there, universal, he deemed so obvious as to be unworthy of emphasis. Robert Hutchins (1969) understood his "university of utopia" in the context of the New World urge to "universal education" available to all (p. 2). Neither interpretation of the English word's Latin source, universitas, is historically instructive. At the time that word was first used for institutions of higher education, it referred to a particular form of association in Roman law, whose name literally meant something like "the whole of you" (Rashdall, 1895, p. 7). The same term was used for craft guilds and other kinds of corporations. It meant "universal" only to the degree that it described a legal unity among some plurality of persons engaged in a common enterprise. Before the university stood for an aspiration to universal knowledge or universal access, it was a particular 
kind of company. This legal sense of the word is all the more significant since the university that was perhaps Europe's first, that of Bologna, was principally a school of law. As recent authority on the matter states, "There was nothing special in the word universitas" (Pedersen, 1997, p. 145).

Yet those lofty aspirations toward which Newman and Hutchins point have a place. Whenever civilizations have given birth to university-like institutions, it has been to protect fragile and precious pursuits. Ephemeral schools of higher education have come and gone around the world for millennia, but the formation of lasting, formal structures represent civilization-making turning points.

In China, by the fourth century BCE, the imperial state saw fit to establish institutions that could serve thousands of scholars at a time, granting them license and resources to pursue wisdom through Confucian texts and ritual expertise. According to Lee (2000), "Confucian teaching is centered on personal enrichment rather than on its usefulness for securing recognition or benefit to one's self" (p. 2). More obviously practical pursuits naturally competed for attention and investment; the structure that most secured a place for the Confucian scholarly ideal, by the medieval Tang and Song dynasties, was the civil-service exam, which enshrined the mastery of certain classical texts as a prerequisite for government employment (Hayhoe, 1989). This worldly technique made more transcendent pursuits, and the universities that supported them, viable as a way of life.

As the Chinese exam system matured, a different kind of higher education began to take hold in Islamic Africa. Small madrasas attached to mosques grew into larger centers of learning such as Al Qaraouyine in Fez, founded in 859 by a wealthy woman from the Tunisian holy city Kairouan. It would attract the region's most eminent scholars, including the historian Ibn Khaldun and the Jewish philosopher Maimonides. Whereas the Chinese system depended on political patronage, the early African universities relied on a feature of Islamic law, the waqf, a sacrosanct trust that preserves endowments of property for charitable and religious purposes (Lulat, 2005). Within that legal and economic fortress, years of study in religious and philosophical matters became tenable; someone might remain a student at an institution like Cairo's Al Azhar for a lifetime. North Africa became the capital of higher learning for the whole Mediterranean region.

A notable difference between these indigenous institutions and the universities that were later formed under colonial rule in Africa and Asia is the commitment to knowledge not oriented around immediate instrumental value. 
The waqf and the civil-service exams enabled and protected those seeking such knowledge, serving as membranes between the scholars and the socioeconomic surround. When colonial regimes arrived, they saw fit to abolish both systems, supplanting them with instrumental facsimiles of the European university model. "The pursuit of knowledge for its own sake," according to one history of African universities, was "jettisoned in favor of an exclusively utilitarian view of higher learning" (Lulat, 2005, p. 3; see also Hayhoe, 1989). But the universities that Europeans installed as colonists were not the kinds of universities they developed for themselves at home.

The European universities had precedents in less formal schools that had existed for centuries, usually attached to rural monasteries, urban cathedrals, or the ad hoc followings of popular intellectuals. But the universitas as such, as a more or less autonomous institution, arose through nearly simultaneous developments in Bologna and Paris, mainly in the trailing decades of the 12th century. Today, as precarity appears to be an ascendant tendency of the social contracts we tolerate (Standing, 2011), the context from which the early universities arose may strike us as familiar. Both cities had become centers of learning for scholars from abroad who lacked citizenship in the local political order (Pedersen, 1997; Rashdall, 1895). Such a gathering place became known as a studium generale; the universitas was the form of legal association that helped secure and direct the studium's activities.

In the case of Bologna, the outsiders were the students, who came to experience the distinct mixture of Roman and Germanic legal traditions in which Bolongnese scholars specialized. Although typically wealthy, these students lacked essential political rights and local knowledge in Bologna, so they formed associations to strengthen their hand in negotiating on matters such as housing costs, tuition, and due process. With support from the Holy Roman Emperor, their corporations gained legitimacy. This system was, and would remain for centuries, the prototype student university, a self-managed association of students that hired teachers and negotiated collectively with the economy around them. They threatened boycotts of their teachers and the city if their demands were not met. As a canonical English-language history of European higher education puts it, "The very existence of the University was due to the want of political status on the part of its members" (Rashdall, 1895, p. 160). There was no fixed campus; part of the university's strength was the threat that it could move the economic benefits of its presence elsewhere.

The late-12th-century situation in Paris was a kind of mirror image of Bologna. 
Rather than a law school catering to adult, well-heeled students, Paris was chiefly an ecclesial school that specialized in theology. The students were younger - generally what we would now call teenagers - and more variable in economic background; both they and the faculty had often traveled from abroad for clerical careers, sharing only Latin as the common language and clustering in what came to be known as the city's Latin Quarter. The university that had formed to oversee this arrangement was a guild of professors, as they were the constituency best suited to wield leverage against municipal authorities in Paris. While in Bologna the outside ally of the university was the Holy Roman emperor, in Paris it was the pope.

In Paris, too, scholars were vulnerable, and not entirely holy. A signal moment in the university's founding, in the year 1200, was a tavern brawl over terms of payment that resulted in the deaths of several students. The resulting settlement placed university affiliates under ecclesial rather than civil jurisdiction.

Both the Bolognese and Parisian models were replicated elsewhere, but Paris was far more so. (A university of faculty also formed in Bologna, although it didn't achieve dominance over the students until the 18th century.) Both organized as a self-governing guild of members, backed by external authority, to ensure that apparently abstract and unmarketable undertakings had a place. Without such work, modern science, philosophy, and industry are unimaginable.

This is the legacy we have to thank for our faculty meetings, along with various regalia and titles. Like the Chinese exam and the Islamic waqf, the institutional adaptation that turned a guild into a university created space for the birth of the next civilization in the midst of a civilization that might not otherwise see the worth of what was to come. "The genius of the Middle Age showed itself above all in the creation of institutions," according to Radshall (p. 709). And to what end were these institutions created? The answer seems deceptively obvious: "To make possible the life of study" (p. 714).

In this light, we might consider another etymological curiosity - that the word school derives from schole, the Greek word for leisure.

\section{Productivity and Productive Leisure}

The university, among the civilizations surveyed, has been a ploy that renders a set of activities not obviously useful to the surrounding society 
into something legible and even valuable. In particular, universities have specialized in protecting time. They organize and baptize, for students, the investment of several years of non-remunerative activity in early adulthood; for career scholars, the system makes possible greater investments in expertise and research. All these investments tend to pay off, for both individuals and their societies. But in order to make such investments, the university is a necessary trick - a form of elemental media that contrives to represent the value of activities whose worth may not otherwise be evident.

Well before the rise of European universities, guilds were organizations for mutual protection. The earliest guilds were at least in part mutual-defense pacts, promising vengeance should harm come to any member, in addition to collectivizing the costs of fraternization and funerals (Epstein, 1991); later, they evolved more abstract forms of protection, such as securing the investment costs of training a young craftsperson and protecting incentives for inventors in lieu of a patent system (Epstein, 1998). The universities adapted guild mechanisms to protect the congress of transnational scholars in certain jurisdictions and to protect their time together.

More specifically, I refer to what universities specialize in protecting as productive leisure. It is productive because it seeks the alchemical promise of generating interpretations and innovations that would not otherwise be available. Yet this process remains leisure because it is significantly free from the demand to extract "deliverables" of immediate value to the outside world (Butler, 2014). University members decide individually and collectively what they value, and they adopt structures and disciplines to organize their efforts. Typically, the most accomplished scholars enjoy the fullest license to pursue matters of least obvious economic value - whether they be inquiries into the origins of the universe or ruminations on the life of the mind.

Universities have been almost uniquely successful at liberating time. Everlarger proportions of the human population, through the university gambit, justify devoting years of their lives to study. This achievement has been surpassed perhaps only by the reductions in working hours achieved through labor unions.

The liberation of time has been a long-promised but little-delivered feature of modern social contracts. Generation after generation expects advances in technology to result in increased quantities of leisure. Hunnicutt (2013) provides the definitive overview of this history in the US context. Far from the Weberian caricature of a "Calvinist ethic" of overwork, the eminent colonial-era Congregationalist theologian Jonathan Edwards took for granted 
that "contrivances and inventions" would "expedite" people's "necessary secular business," leaving "more time for more noble exercise" (p. 15; see also Schneider, 2014). He, together with influential preachers who followed him after independence, hoped that such freed-up time would be used for pious activities. Edwards was not a natural educator-he died shortly after reluctantly assuming the presidency of what is now Princeton Universitybut in the 20th century it was educators who took up the subject of leisure where he and the other preachers left off (Gershon, 2014). In his 1912 address to the Modern Language Association as chairman, Frank Gaylord Hubbard (1912) reminded his colleagues of the leisure for study that attracted so many of them to the teaching profession in the first place, and he called for a revival of "a true revival of learning" in society, which would mean ensuring "more leisure for education and more education for leisure" (pp. lxxix-xc). He assumed that a six-hour standard workday was already attainable. A decade later, Chicago-area English school teacher Althea A. Payne (1921) worried about the ascendant movement for a 42-hour workweek and challenged her profession, "It is our duty as educators to equip the boys and girls in our care with interests and ideals that shall urge them to use this leisure profitably" (p. 209). On the eve of the Great Depression, the eminent economist John Maynard Keynes predicted that his grandchildren would have to learn to live with a workweek of just 15 hours (Keynes, 2010 [1930]); during the postwar economic boom, the former University of Chicago president Robert Hutchins (1969) expected universal joblessness by the turn of the millennium and envisioned the liberal arts as a means for training people to put their expanding leisure time to proper use.

"We are going to live in a wantless, workless world," he predicted. "The machines will do the work" (p. vii) - and the university would have to prepare people for everything else.

Today, visible especially through the growing interest in universal basic income, expectations of near-future leisure (or else cataclysmic unemployment) are experiencing a revival (e.g., Brynjolfsson \& McAfee, 2016; Van Parijs \& Vanderborght, 2017). That is one side of the "free time" legacy that Hunnicutt chronicles - the expectation that such time would come inevitably, like a thief in the night. But the lived reality of obtaining free time has been much more a contest of value-capture through struggle.

During the late 20th and early 21st centuries, the often militant labor movements on both sides of the Atlantic regarded a reduction in working hours as a chief demand - "not just bread, but roses, too," as the reformer 
Rose Schneiderman and others preached (Brooks, 1912). First for a 10-hour cap, and then eight, workers undertook a decades-long effort that was both deadly (as in the Chicago Haymarket riots celebrated worldwide on May Day) and successful. Yet after the enshrinement of an eight-hour standard, the struggle for time fell dormant. Economic productivity per worker-hour has continued to increase, but working hours, as well as wages, have held relatively steady (Aguiar \& Hurst, 2007; Michel, 2012). Ever more people have lost access to stable hours and wages altogether (Standing, 2011).

Among the most lucid thinkers on leisure and labor struggles, especially in the context of greater automation and service work, is André Gorz. Unlike many of his contemporaries, he didn't expect rising productivity to translate automatically into ubiquitous leisure. Rather, he regarded leisure as a choiceone that could not be made within the confines of "economic reason" alone; institutions accountable not chiefly to market outcomes would be necessary to accumulate leverage necessary to choose and demand it. "History may place the opportunity for greater freedom within our grasp," he wrote, "but it cannot release us from the need to seize this opportunity for ourselves and derive benefit from it." (Gorz, 2011, p. 185) Toward the end of his life, in the early 2000s, Gorz came to see knowledge work, and the university in particular, as a strategic site for such grasping (Poltermann, 2014).

Without struggle and institutional change, the promised dividend of leisure does not appear to manifest on its own. Rather, the dividend appears to be concentrated in the form of profits to capital-holders (Alvaredo, Atkinson, Piketty, \& Saez, 2013). Meanwhile, proposals for the future of higher education have tended toward a posture of market adaptation, either by imitating the idiom of the entrepreneurial class (Etzkowitz et al., 2000) or instituting "vocational"1 retraining programs for displaced workers (Selingo, 2018). These strategies fall far short, however, of the sort of role that higher education has played in its origin stories - establishing and protecting the value of activities not otherwise valued by the outside society, so successfully as to transform that society and what it values.

To recognize higher education as a champion of productive leisure is to reclaim that former role, short of mere nostalgic recapitulation. The university can be a means - not the only one, but an essential one - of finally obtaining the due dividend from widespread productivity and realizing a society in which full-time employment is less necessary for more people than it is today. As

\footnotetext{
${ }^{1}$ I use scare quotes because the now-commonplace usage (pertaining to mere jobs) is a near total reversal of the word's classical meaning (pertaining to a person's higher calling).
} 
in earlier times, this is a transformative project in which the university, if effectively constituted, can exert decisive leverage. The university of utopia that Hutchins envisioned might not be so distant.

\section{Higher Education as Productive}

Even if the premodern institutions of higher education defied the usual determinants of value around them, they were nevertheless built on a presumption that they would be productive. The Chinese system bore the Confucian premise that textual and ritual study would produce more effective administrators for the imperial state. The Islamic universities grew from a legal and theological paradigm of autonomous charitable trusts, and their students produced professions from religious law to medicine, in which philosophers like Ibn Rushd and Maimonides would frequently find employment. The fact that the European universities would borrow their legal grammar from the craft guilds was no aberration; whether they were faculty or students, members of a university saw themselves as engaged in pursuits as worthy of self-organization and recognition as any profession.

The most direct descendant of the guild in the industrial era and beyond is the cooperative. Cooperatives employ roughly 10 percent of the global labor force in enterprises ranging from credit unions to farming, manufacturing, and retail (International Co-operative Alliance, n.d.-b). More than the charitable corporations that tend to house leading universities, this is a corporate form designed to harness productive activities, capturing and distributing surplus value to those who participate in generating it. Unlike private, for-profit universities, cooperatives prevent the capture of that value by outside investors. Co-ops played a considerable minority role in forming the industrial world, and the model has aroused growing interest and experimentation among people confronting the challenges of post-industrial, networked economies (Conaty, Bird, \& Ross, 2018; Schneider, 2018b). This contribution, however, has been widely disregarded in business and economics education (Schneider, 2016). For societies increasingly organized over online platforms, the framework known as platform cooperativism (Schneider, 2018a; Scholz \& Schneider, 2016) is especially relevant. Conceiving of the university as a platform allows for the embrace of diverse media as its points of connection, from transnational campuses to MOOCs; insisting on cooperativism means ensuring that the value of those connections are democratically shared and governed. 
Neary \& Winn (2009) proposed a theoretical and pedagogical intervention of recognizing the "student as producer" in higher education. This was based on a fuller appreciation of unacknowledged production that students already undertake, as well as the promise of an educational experience in which participatory research supplants the posture of "student as consumer." Subsequent proposals (e.g., Winn, 2015; Neary \& Winn, 2017) re-imagine the university as a worker-owned cooperative among its constituent contributors, from students and faculty to service workers. Given the decline in public investment in higher education, coupled with the abuses of forprofit alternatives, the cooperative represents a uniquely appropriate middle ground.

Neary \& Winn (2017) argue that the form known as the "social cooperative" holds particular promise. This model first appeared in Italy, starting in the 1970s, as a vehicle for the provision of state-funded medical and care services (Thomas, 2004). Whereas co-ops have conventionally been organized around one stakeholder class - that is, workers or customers or businesses social co-ops tend to be multi-stakeholder, integrating in their ownership and governance a more diverse set of participants. For instance, a homecare co-op might include members who are employee caregivers as well as patients, their family members, and local organizations engaged in public health advocacy. In Italy and elsewhere, this model has proved effective in delivering high-quality, low-cost services, paid for both by government funds and private clients.

A university is an intrinsically multi-stakeholder institution, and modern universities typically include a variety of organized factions, from faculties to residential colleges, from student governments to service-worker unions. A university could collect all these groups into one multi-stakeholder cooperative, or else operate as a collection of single-stakeholder cooperatives acting in tandem.

In their multi-stakeholder structure, universities are more akin to platform enterprises, which create value by facilitating connections among users (Parker, Alstyne, \& Choudary, 2016), than to industrial production and distribution. Their productivity thus lies principally in the free exchange they enable. The governance of such exchange is a complex, delicate task, which cooperative structures can facilitate through the trust-building capacity of shared ownership (Hansmann, 1996).

What keeps cooperative governance accountable is the entity's capacity for capturing, holding, and collectivizing wealth on behalf of its members. 
Like both social cooperatives and universities today, the wealth might come from market transactions, philanthropy, and taxation-based public support. But rather than regarding students as merely clients and faculty as merely job-holders, the university would be accountable to them as owners. Such ownership can encompass various roles; students might receive stipends to support their productive leisure, which might be paid for with stock dividends from future employers or startups. Tuition might be expected for purely professional degrees. While the outcomes of research should be openly accessible, the university can be more aggressive in claiming an equity stake in any market commercialization.

An instructive method for networked value creation through leisure is that of "peer production," employed especially by free/libre/open-source software (FLOSS) communities, such as those that support the GNU/Linux operating system and the WordPress blogging platform (Coleman, 2013). While this paradigm has been remarkable in harnessing widespread, free-will contributions for productive ends, its production has generally remained available for corporate value-capture, such as Alphabet's use of the Linux kernel in its surveillance-oriented Android mobile operating system. But such outcomes need not result from FLOSS-like production. Dmytri Kleiner (2010), for instance, proposed a "Peer Production License," which would preserve content for free circulation and utilization by nonprofits and cooperatives while requiring separate license agreements in cases of for-profit commercialization. This and similar interventions can be used to ensure both free exchange of ideas and value retention by universities and their members.

Over the course of their lives, members might opt to move back and forth between employment in the market and the university - perhaps for a few years at a time, or perhaps for part of every week. People might switch universities as their needs change, and they might rotate among teaching, learning, and research. These roles could be fulfilled on a campus or off. Thus the university becomes less a fixed set of prescribed early-adulthood experiences and more a platform for lifelong productive leisure.

Such an arrangement need not require entirely new institutions; just as medieval universities grew from the waqf and the guild, the next universities can emerge by building on and amplifying latent tendencies. For instance, Deep Springs College in California and Berea College in Kentucky already provide free education for all students, coupled with a universal expectation for productive employment. Extractive student loan programs could be replaced with wealth-building mechanisms like a leveraged employee stock- 
ownership trust (Hockett, 2007; Kelso \& Kelso, 1986). Existing alumni networks would be all the more robust if they were bound with co-ownership and the promise of lifelong participation.

Many university communities already benefit from co-op student housing and co-op student jobs; some have organizations, like the University of Massachusetts Amherst's Cooperative Enterprise Collaborative, that promote such enterprises. California's community colleges, while developing a strategy for introducing their students to the gig economy, passed over large investor-owned gig-work platforms in order to collaborate with Loconomics, a cooperative platform in which workers become co-owners (Schneider, 2018b, pp. 153-154).

These tendencies can be expanded in strategic fashion - through cooperative research centers, cooperative teaching programs, leveraged trusts, lifelong membership, and more - to turn the university from a consumer-service model back toward its origins, toward the purpose of liberating time for productive leisure. In medieval Europe, universities enabled rights-poor foreigners to gain due process and collective bargaining, so their education could be allowed to transform the society around them; today, universities can be a vehicle for finally translating our societies' collective productivity into a dividend of self-directed time.

\section{Higher Education as Leisure}

The most widely discussed proposal associated with liberating time today is universal basic income (UBI) - an unconditional, regular cash payout to all citizens of a given jurisdiction. This proposal, while not new, has attracted renewed interest in recent years from advocates as diverse as feminist Marxists (Weeks, 2011), right-wing libertarians (Murray, 2006), and at least two founders of Facebook (Hughes, 2018; Zuckerberg, 2017), among other Silicon Valley luminaries. Some deem it an inevitable outcome of impending automation-induced unemployment, or at least a necessary bulwark against growing wealth inequality. Experimental evidence suggests that UBI recipients, in addition to experiencing better health outcomes, would choose to pursue more education than they otherwise might (Forget, 2011). The renewal of higher education as a medium for productive leisure would thus be a likely outcome of a UBI program. Perhaps UBI is the proper horse, behind which the university is just one in its train of carts. 
Marina Gorbis (2017), however, raises the concern that the inequality of income distribution is only a subset of the larger inequality of asset distribution. She contends it would be more helpful to think in terms of "universal basic assets" than UBI. To put it another way, we should be concerned about the means of production before the means of consumption. ${ }^{2}$ Recent experience of labor's declining share of wealth (Michel, 2012) suggests that fixed wage income - whether resulting from a job or a UBI - stands at a disadvantage against the direct ownership of capital assets, such as real estate, financial securities, or data. Further, wage-based livelihoods can instill a form of dependency, compelling recipients either to deliver their time to the hours expected of a job or deliver their allegiance to the productive sources of a UBI.

This concern, among others was raised as well by André Gorz (2011). "By this payment," he wrote, "it holds me in its power: what it grants me today, it can take away bit by bit, or altogether, tomorrow, since it has no need of me, but I have need of it" (p. 207). He emphasizes, further, that leisure cannot come at the cost of leverage, of participation, of democracy. "This is the essential point: that control over the economy should be exercised by a revitalized society" (p. 212).

Time is itself a capital asset. Perhaps it should be a universal basic asset as well. Access to leisure is a prerequisite for entrepreneurship, invention, artistic explorations, democratic participation, introspection, and other activities that accompany productive lives. Higher education, another productive asset, depends on leisure as well.

Leisure is the basis of any higher education designed for purposes beyond direct job training. University students and faculty may be very busy, but their time on the whole is far less structured than that of typical jobholders. Learning to organize one's time productively is part of the hidden curriculum embedded in university life. (Another frequent part of that curriculum, ritualized drinking, has been remarkably persistent from 12th century Paris to today.) Such productive leisure, I have argued, is part of what institutions of higher education in diverse contexts were first developed to enable and protect. It has remained endemic to higher education, even if rarely appreciated as such. If universities are to renew their purpose for an economy in which job-holding bears declining importance and leverage, they are uniquely poised to lead a shift toward expanding access to productive

\footnotetext{
${ }^{2}$ For this distinction, I am grateful for a remark by Ed Whitfield at the Left Forum in 2015. See also Whitfield (2017).
} 
leisure.

What would the university of leisure look like? I defined productive leisure above as "self-directed time organized to meet collectively agreed-upon standards"; this is not so different from what universities already do, at their best. As they do today, various institutions would have their own specialties, as well as variety within them. Some members might choose to direct their time to sports or video games or the arts, while others might seek to excel in scientific research and others in examining ancient texts. Receiving support would depend on agreements among peers that a given person's contributions are meaningful. The productivity of those contributions would benefit the contributors as well as the co-owned institution as a whole. To support their productive leisure, members might receive short-term stipends and long-term equity.

It is not my intent here to delve too far into the business of details; those are for more minds and experiences than mine to determine. But the critical pivot I propose is that the university reorient its public mission from selling an inefficient job-training product to offering a platform for liberated time. Such a university doesn't just anticipate the discipline of the market but operates according to values the market hasn't yet learned how to value.

Past experience suggests that widespread leisure will not arise on its own. Productivity has increased through technological and other means, just as Jonathan Edwards and John Maynard Keynes predicted; the dividend of free time didn't follow because there were not institutional structures to compete with those few asset-holders who were able to capture and accumulate most of the surplus for themselves. This may be leading to a new feudalism of precarious, gig-based serfdom. Yet the ubiquity, scale, and mission of the university system makes it a plausible candidate for stemming that tide, for redirecting the widespread surplus into widespread leisure. Such a future of leisure is not inevitable; it must be arranged for institutionally.

Although Robert Hutchins underestimated the ease with which leisure would soon arise, he cast a model of institutional creativity in his efforts to ensure that the coming leisure would be filled with education more than frivolous entertainments. Through his leadership roles at the University of Chicago and the Ford Foundation, he established Great Books courses for adults and helped develop what became the Public Broadcasting Service. Like the lifelong students at Al Azhar in medieval Cairo, he sought to fashion institutions to ensure that education would be not just a preparation for life but a way of life. This kind of creativity, and more, will be needed to turn 
the commitment to productive leisure into a program of institutional reform.

I am probably not the only university instructor who has perceived how poor the media of semesters, lectures, seminars, and term papers are for the job-training we find ourselves increasingly enjoined to provide. That is no accident; this is not the purpose for which these practices formed. There are more efficient and effective ways to learn how to do jobs, as employers well know. What universities are uniquely suited for is the kind of productivity that happens through curiosity and self-management. It is strange that, at a time when the possibilities for leisure have never been greater, universities appear to be heading elsewhere. Perhaps if these institutions centered their purpose around productive leisure, their apparent inefficiencies-including their faculty meetings - would make a fresh kind of sense.

\section{Between Leisure and Discipline}

I have made an ambitious proposal for the renewal of the university, inviting it to become at least as vital and transformative an institution as it has been in times past. Yet I do so with trepidation, with the concern that the liberating tendencies of higher education might be overshadowed by its disciplinary - even oppressive - tendencies. Some degree of organizational

discipline is necessary, ensuring that the leisure of higher education is also productive. Such discipline can be arrived at in collaborative, democratic fashion and leave ample room for flexibility, exploration, and dissent. But the need for discipline can easily extend into overreach.

Discipline goes back to the origins of higher education, just as liberation does. The students' university of medieval Bologna imposed a strict regimen over the timing and content of faculty lectures, to the point of fining a professor if he opted to skip a chapter in the textbook or save a particularly difficult passage for the end of a session (Rashdall, 1895, p. 198). It is little surprise that Bologna's faculty formed their own guilds to adjust the balance of power. And despite the self-government that the faculty of Paris enjoyed, representatives of Rome policed their teachings for the whiff of heresy. The Islamic and Chinese institutions operated under ideological and political constraints of their own. As Pedersen (1997) emphasizes, the early university was forged through conflict.

When compared with the opportunities for free thought and study outside university settings, however, such constraints were relatively lenient. Each of 
these institutional formations made possible forms of life relatively protected from the immediate demands of the social order outside them, enabling productive leisure through study, research, and teaching. In comparison, the institutions of higher education developed under colonial regimes, both by the colonizers and the colonized, notably reduced opportunities for such leisure. They recast higher education into merely instrumental forms. Productive leisure, especially according to standards set by participants, doesn't sit well with the task of subjugation.

It is by no means original to say that such habits are taking hold ever more across higher education today (e.g., Giroux, 2013). The most elite schools might remain aloof from such outright "vocational" programs as accounting, auto repair, and military science, but nevertheless they present the value of a liberal education to parents of prospective students in terms of future market opportunities, rather than intrinsic worth, much less leisure. Self-directed time in research and teaching falls victim to market and technological imperatives (Hayes \& Jandrić, 2017). Protecting space and time for productive leisure is a decolonizing project, especially when it liberates the time of those - the working poor, the colonized, the "at risk" - who have typically not been entrusted with opportunities for leisure (Shippen, 2014). Productive leisure invites people to organize their own curricula and goals, to define for themselves what to do with their time. As stewards of asset wealth, universities should do more to ensure that those who otherwise lack capital access will be the first to obtain it. In this way, again, these institutions can recognize potential value where others fail to notice it.

The need for such decolonization is as evident in Britain and France and the United States as in South Africa and Bangladesh. Anti-colonial thinkers have frequently coupled the task of centering indigenous knowledge in the curriculum with that of protecting university time from the demands of global markets. Achille Joseph Mbembe (2016) writes, for instance, "We need to decolonize the systems of access and management insofar as they have turned higher education into a marketable product" (p. 30). Alongside calls for African languages in African universities, he decries the time-consuming "mania" for quantitative assessment and the presumption of servitude to profit-seeking business. If the university is to take a leading role in shaping the next social contracts, we should be anxious to dispense with its marketsubservient tendencies.

Self-governance is a deft means of righting the balance between leisure and discipline. For all its disciplinary constraints, the medieval university 
retained autonomy by being meaningfully democratic; members elected their leaders from among themselves, thereby co-designing the terms of their endeavors. Today, forms of cooperative organization offer a means of pairing such democracy with co-owned wealth. Cooperatives, according to their set of international principles (International Co-operative Alliance, n.d.-a), are voluntary, so no such institution should be compulsory (Illich, 1971); other kinds of institutions can meanwhile offer their own strategies for liberating time that would appeal to people uninterested in a lifelong relationship to higher education. But I suspect universities are especially well suited to the task.

If universities are not ready to adopt this transformative role in expanding opportunities for productive leisure, other institutions may do so, perhaps relegating universities to the obsolescence that many technologists now predict (e.g., Guerriero, 2014). The urge to groom students for future marketability may be too ingrained. A government-funded UBI might do just as well or better at expanding leisure, or entirely new kinds of institutions could arise for the task. Universities, at least, have the virtue of already existing, holding significant wealth and power, and building on a legacy of having enabled past economic transitions through productive leisure. But free time has never arrived by its own volition. It begins when people recognize themselves as worthy of lives freer from want and work.

\section{References}

Aguiar, M., \& Hurst, E. (2007). Measuring Trends in Leisure: The Allocation of Time Over Five Decades. The Quarterly Journal of Economics, 122(3), 969-1006. https://doi.org/10.1162/qjec.122.3.969

Alvaredo, F., Atkinson, A. B., Piketty, T., \& Saez, E. (2013). The Top 1 Percent in International and Historical Perspective. Journal of Economic Perspectives, 27(3), 3-20. https://doi.org/10.1257/jep.27.3.3

Brooks, M. K. (1912). Votes for Women: Rose Schneiderman in Ohio. Life and Labor, 288.

Brynjolfsson, E., \& McAfee, A. (2016). The Second Machine Age: Work, Progress, and Prosperity in a Time of Brilliant Technologies. New York London: W. W. Norton \& Company.

Butler, J. (2014). Ordinary, Incredulous. In P. Brooks (Ed.), The Humanities 
and Public Life (pp. 15-38). Fordham University Press. https://doi.org/10. 5422/fordham/9780823257041.003.0002

Coleman, E. G. (2013). Coding Freedom: The Ethics and Aesthetics of Hacking. Princeton: Princeton University Press.

Conaty, P., Bird, A., \& Ross, C. (2018). Working Together: Trade Union and Co-operative Innovations for Precarious Workers. Co-operatives UK.

Epstein, S. A. (1991). Wage Labor and Guilds in Medieval Europe. UNC Press Books.

Epstein, S. R. (1998). Craft Guilds, Apprenticeship, and Technological Change in Preindustrial Europe. The Journal of Economic History, 58(3), 684-713. https://doi.org/10.1017/S0022050700021124

Etzkowitz, H., Webster, A., Gebhardt, C., \& Terra, B. R. C. (2000). The Future of the University and the University of the Future: Evolution of Ivory Tower to Entrepreneurial Paradigm. Research Policy, 29(2), 313-330. https://doi.org/10.1016/S0048-7333(99)00069-4

Forget, E. (2011). The Town with No Poverty: The Health Effects of a Canadian Guaranteed Annual Income Field Experiment. Canadian Public Policy, 37(3).

Gershon, L. (2014, December). The Rise and Fall of "Education for Leisure". JSTOR Daily.

Giroux, H. A. (2013). Public Intellectuals Against the Neoliberal University. Truthout.

Gorbis, M. (2017, October). To Fix Income Inequality, We Need More Than UBIWe Need Universal Basic Assets. Quartz.

Gorz, A. (2011). Critique of economic reason (2nd ed.). London: Verso.

Guerriero, M. (2014). Are College Campuses Obsolete? The New Yorker.

Hansmann, H. (1996). The Ownership of Enterprise. Cambridge, MA: Harvard University Press.

Hayes, S., \& Jandrić, P. (2017). Learning, Technologies, and Time in the Age of Global Neoliberal Capitalism. Knowledge Cultures, 5(2), 11-17.

Hayhoe, R. (1989). China's Universities and Western Academic Models. Higher Education, 18(1), 49-85. https://doi.org/10.1007/BF00138961 
Hockett, R. (2007). What Kinds of Stock Ownership Plans Should There Be - Of ESOPs, Other SOPs, and Ownership Societies. Cornell Law Review, 92(5), 865 .

Hubbard, F. G. (1912). The Chairman's Address: Education and Leisure. PMLA, 27, lxxi-xc. https://doi.org/10.2307/456700

Hughes, C. (2018). Fair Shot: Rethinking Inequality and How We Earn. New York: St. Martin's Press.

Hunnicutt, B. K. (2013). Free Time: The Forgotten American Dream. Philadelphia: Temple University Press.

Hutchins, R. M. (1969). The University of Utopia (2nd ed.). Chicago: University of Chicago Press.

Illich, I. (1971). Deschooling society (1st ed.). New York: Harper \& Row.

International Co-operative Alliance. (n.d.-a). Co-operative Identity, Values \& Principles. https://ica.coop/en/whats-co-op/co-operative-identity-valuesprinciples.

International Co-operative Alliance. (n.d.-b). Facts and Figures. https://ica.coop/en/facts-and-figures.

Kelso, L. O., \& Kelso, P. H. (1986). Democracy and Economic Power: Extending the ESOP Revolution through Binary Economics. Cambridge, MA: Ballinger Publishing.

Keynes, J. M. (2010). Economic Possibilities for Our Grandchildren. In Essays in Persuasion (pp. 321-332). Palgrave Macmillan, London. https: //doi.org/10.1007/978-1-349-59072-8_25

Kleiner, D. (2010). The Telekommunist Manifesto. Amsterdam: Institute of Network Cultures.

Lee, T. H. C. (2000). Education in Traditional China: A History. Brill.

Lulat, Y. G.-M. (2005). A History of African Higher Education from Antiquity to the Present: A Critical Synthesis. Westport, Conn.: Praeger Publishers.

Mbembe, A. J. (2016). Decolonizing the University: New Directions. Arts and Humanities in Higher Education, 15(1), 29-45. https://doi.org/10.1177/ 1474022215618513 
Michel, L. (2012). The Wedges Between Productivity and Median Compensation Growth. Economic Policy Institute Issue Brief, (330).

Murray, C. (2006). In Our Hands : A Plan To Replace The Welfare State. Washington, D.C.: AEI Press.

Neary, M., \& Winn, J. (2009). The Student as Producer: Reinventing the Student Experience in Higher Education. In The future of higher education: Policy, pedagogy and the student experience (pp. 192-210). London: Continuum.

Neary, M., \& Winn, J. (2017). Beyond Public and Private: A Framework for Co-operative Higher Education. Open Library of Humanities, 3(2). https://doi.org/10.16995/olh.195

Newman, J. H. (1905). The Idea of a University Defined and Illustrated. Longmans, Green, and co.

Parker, G. G., Alstyne, M. W. V., \& Choudary, S. P. (2016). Platform Revolution: How Networked Markets Are Transforming the Economyand How to Make Them Work for You. W. W. Norton \& Company.

Payne, A. A. (1921). Education for Leisure as Well as for Vocation. The English Journal, 10(4), 208. https://doi.org/10.2307/802122

Pedersen, O. (1997). The First Universities: Studium Generale and the Origins of University Education in Europe. Cambridge: Cambridge University Press.

Peters, J. D. (2015). The Marvelous Clouds: Toward a Philosophy of Elemental Media. Chicago: University of Chicago Press.

Poltermann, A. (2014, April). André Gorz's Concrete Utopia of the Knowledge-Based Society. Heinrich Böll Stiftung Serbia, Montenegro, Kosovo. https://rs.boell.org/en/2014/04/29/andr\%C3\%A9gorz $\% \mathrm{E} 2 \% 80 \% 98$ s-concrete-utopia-knowledge-based-society.

Rashdall, H. (1895). The Universities of Europe in the Middle Ages. Oxford: Clarendon Press.

Schneider, N. (2014). More Noble Exercise. Lapham's Quarterly.

Schneider, N. (2016). Curricular Cop-out on Co-ops. The Chronicle of Higher Education. 
Schneider, N. (2018a). An Internet of Ownership: Democratic Design for the Online Economy. The Sociological Review, 66(2).

Schneider, N. (2018b). Everything for Everyone: The Radical Tradition That Is Shaping the Next Economy. New York: Nation Books.

Scholz, T., \& Schneider, N. (2016). Ours to Hack and to Own: The Rise of Platform Cooperativism, a New Vision for the Future of Work and a Fairer Internet. New York: OR Books.

Selingo, J. (2018). The False Promises of Worker Retraining. The Atlantic.

Shippen, N. M. (2014). Decolonizing Time: Work, Leisure, and Freedom. New York: Palgrave Macmillan.

Standing, G. (2011). The Precariat: The New Dangerous Class. London: Bloomsbury Academic.

Thomas, A. (2004). The Rise of Social Cooperatives in Italy. Voluntas: International Journal of Voluntary and Nonprofit Organizations, 15(3), 243263. https://doi.org/10.1023/B:VOLU.0000046280.06580.d8

Van Parijs, P., \& Vanderborght, Y. (2017). Basic Income: A Radical Proposal for a Free Society and a Sane Economy. Cambridge, MA: Harvard University Press.

Weeks, K. (2011). The Problem with Work: Feminism, Marxism, Antiwork Politics, and Postwork Imaginaries. Durham: Duke University Press Books.

Whitfield, E. (2017, January). Nevermind Guaranteed Income, We Want the Cow. Fund for Democratic Communities. https://f4dc.org/2017/nevermindguaranteed-income-we-want-the-cow/.

Winn, J. (2015). The Co-operative University: Labour, Property and Pedagogy. Power and Education, 7(1), 39-55. https://doi.org/10.1177/ 1757743814567386

Zuckerberg, M. (2017, July). Facebook. Facebook. 